\title{
Runoff and drainage pattern derived from digital elevation models, Finsterwalderbreen, Svalbard
}

\author{
Jon Ove Hagen, ${ }^{1}$ Bernd Etzelmüller, ${ }^{1}$ Anne-Marie Nuttall ${ }^{2}$ \\ ${ }^{1}$ Department of Physical Geography, University of Oslo, P.O. Box 1042 Blindern, N-0316 Oslo, Norway \\ ${ }^{2}$ Bristol Glaciology Centre, School of Geographical Sciences, University of Bristol, Bristol BS8 1SS, England
}

\begin{abstract}
Finsterwalderbreen $\left(77^{\circ} 26^{\prime} \mathrm{N}, 15^{\circ} 15^{\prime} \mathrm{E}\right)$ is a $35 \mathrm{~km}^{2}$ polythermal, surgetype glacier in southern Spitsbergen, Svalbard. Extensive field investigations have been carried out on the glacier, including mapping of bed topography by radio-echo soundings, mass-balance measurements and hydrological and meteorological registrations. In this paper we have used surface and bed topography and observations of summer ablation to estimate total runoff and subglacial drainage pattern by means of spatial map analysis in standard geographic information system software. The location and relative importance of the water-channel outlets from the glacier were estimated, as well as the change in drainage pattern over the period 1970-90. The results could be compared to direct observations of drainage pattern and discharge recordings. The analyses indicate that the location of the subglacial channels is dominated by the surface topography and thus that the channels are partly pressurized.
\end{abstract}

\section{INTRODUCTION}

The glacier-hydrological setting seems to be a major factor for surge behaviour of glaciers (Paterson, 1994). It is now well known that the subglacial drainage system changes dramatically during a surge (Kamb and others, 1985; Kamb, 1987; Björnsson, 1998). This study aims to increase knowledge of the hydrological conditions of Finsterwalderbreen, southern Spitsbergen, Svalbard, which may be significant for understanding future surge events. We have used spatial analysis capabilities within a geographic information system (GIS) to reveal basic hydrological characteristics beneath Finsterwalderbreen, based on digital elevation models (DEMs) from the glacier surface in 1970 and 1990, and the subglacial topography. The main objectives of this study are to:

estimate the location of subglacial drainage ways and their pressure conditions

evaluate how they have changed over a 20 year period

estimate the amount of water in the different water channels during a year.

\section{FINSTERWALDERBREEN}

Finsterwalderbreen $\left(77^{\circ} 26^{\prime} \mathrm{N}, 15^{\circ} 15^{\prime} \mathrm{E}\right)$ is a $35 \mathrm{~km}^{2}$ polythermal, surge-type glacier (Figs 1 and 2). It has been the subject of glaciological studies since 1950, mainly mass-balance studies (Hagen and Liestøl, 1990). Extensive studies started in 1994 through a joint project between scientists from the U.K., France and Norway in a European Union (EU) Environment Programme, to determine the glaciological characteristics of a typical polythermal Svalbard valley glacier in a pre-surge stage. These studies included mass-balance measurements, geometry changes and dynamic changes (Nuttall and others, 1997), mapping of the thermal regime (Ødegård and others, 1997), sediment transport and hydrological measurements (Hodson and others, 1997; Wadham and others, 1997).

The glacier is a well-defined cirque glacier about $11 \mathrm{~km}$ long and around 150-200 m thick along most of the centre flowline. The glacier last surged between 1898 and 1910 (Liestøl, 1969). Since its last surge the glacier geometry has gradually evolved to a surface profile similar to the presurge topography in 1898. The glacier may be approaching a new surge as present-day mass balance and observed ice flux indicate that only about $60 \%$ of the accumulated mass

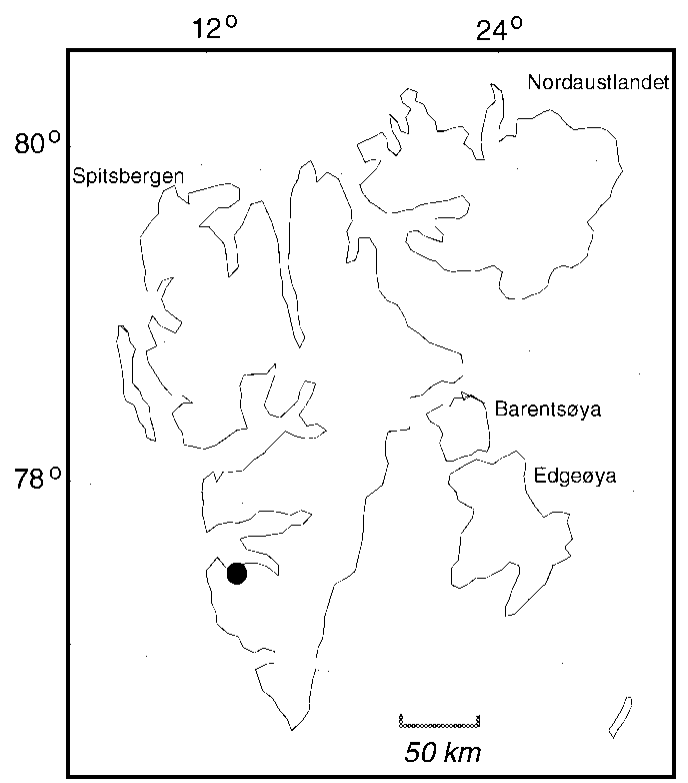

Fig. 1. Location of Finsterwalderbreen in Svalbard. 


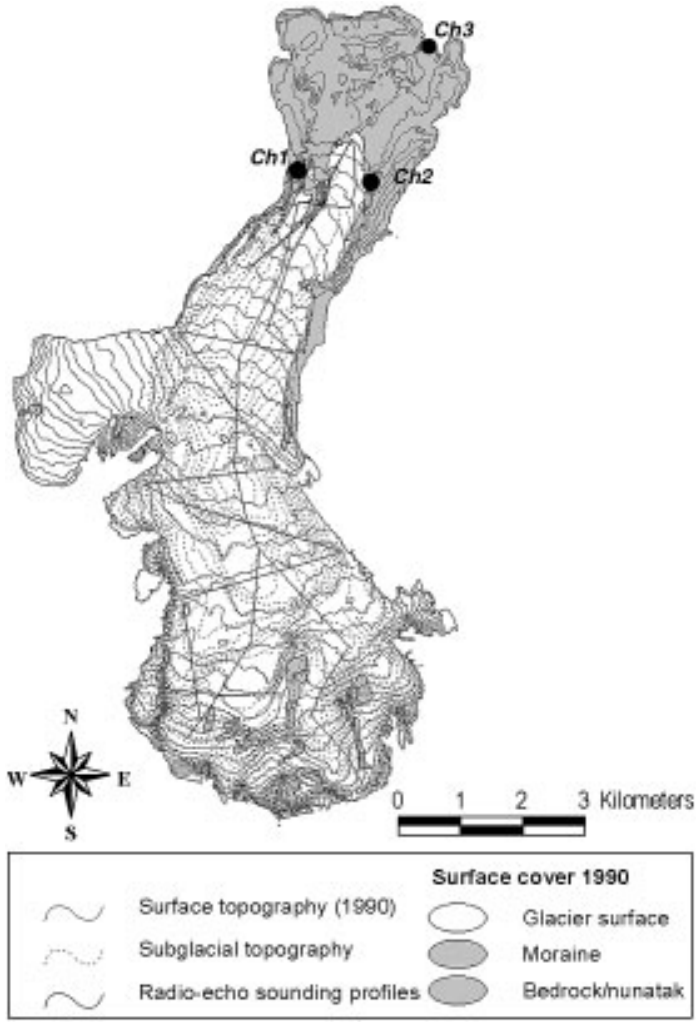

Fig. 2. Finsterwalderbreen in 1990 with surface topography, radar profiles and bed topography based on manual interpolation from the radar profiles. The original map has $10 \mathrm{~m}$ contour lines; here only $20 \mathrm{~m}$ contour lines are given. The channel outlets from the glacier are Ch1 and Ch2, and the confluent stream is Ch3.

is transported down to the ablation area, with surface velocities of about $7 \mathrm{~m} \mathrm{a}^{-1}$ at the equilibrium-line altitude (ELA) (Nuttall and others, 1997).

The thermal structure of the glacier has been mapped using high-frequency radar soundings (320-370 MHz), in addition to high-resolution thermistor measurements in three boreholes in the accumulation and ablation area (Ødegård and others, 1997). This has proved to be a reliable method on other glaciers in Svalbard (Björnsson and others, 1996). The radar results show that there is an upper cold ice layer of variable thickness underlain by temperate ice. The thickness of the cold layer ranges from 25 to $170 \mathrm{~m}$. These large differences are mainly caused by variations in snow accumulation and superimposed-ice formation that lead to variations in the downward heat transfer by refreezing of meltwater. The glacier is at the pressure-melting point over most of its bed except in the lowermost 500-700 $\mathrm{m}$ from the terminus.

\section{DATASETS AND MAP ANALYSIS}

\section{Surface topography}

The DEMs are based on maps made from air photographs taken in 1970 and 1990. The 1970 DEM is derived from a map at a scale of 1:25000 with 10 m contour lines (C) Norsk Polarinstitutt), by scanning and vectoring the contours. Gridding to 25 and $50 \mathrm{~m}$ resolution was then carried out following Hutchinson's (1989) procedure. Relative accuracies are estimated to be within $3 \mathrm{~m}$. The 1990 DEM was generated using an analytical plotter (Fox and Nuttall, 1997) based on air photos at a scale of 1:50000. Relative accuracies are here within $2 \mathrm{~m}$.
Subtracting the 1970 DEM from the 1990 DEM (Fig. 3) reveals the long-term surface elevation change, which can be used as a measure of long-term mass change. Above about $400 \mathrm{~m}$ a.s.l., the glacier has generally built up by up to $10 \mathrm{~m}$ while the front has retreated and the lower part of the glacier has melted down up to 40-50 m over the 20 year period. This resulted in a clear steepening of the glacier surface (Nuttall and others, 1997). Changes of the glacier surface geometry during this period are also discussed in Etzelmüller and Sollid (1997) and Etzelmüller (2000).

\section{Bed topography}

Information about glacier thickness was obtained by radioecho soundings using a time-gain synthetic pulse radar (Hamran and Aarholt, 1993). The frequency bandwidth of the system is $0.1 \mathrm{MHz}$ to $3 \mathrm{GHz}$, and a dipole antenna was used for 30-80 MHz for the mapping of the bed topography. In addition, a low-frequency monopulse radar with centre frequency $8 \mathrm{MHz}$ was applied. All radar soundings were ground-based as the radar and antennae were mounted on a sledge behind a snowmobile. The radar profiles were positioned by kinematic global positioning system (Fig. 2).

There are several methods available for interpretation of ice-thickness data, interpolation techniques and statistical analysis to obtain a reliable bed-topography map and a DEM. Our bed-topography map is based mainly on manual interpolation which often gives more reliable results than automatic interpolation routines in the case of irregularly spaced radio-echo lines. This requires some local knowledge, and details will often be a result of subjective evaluation. It is

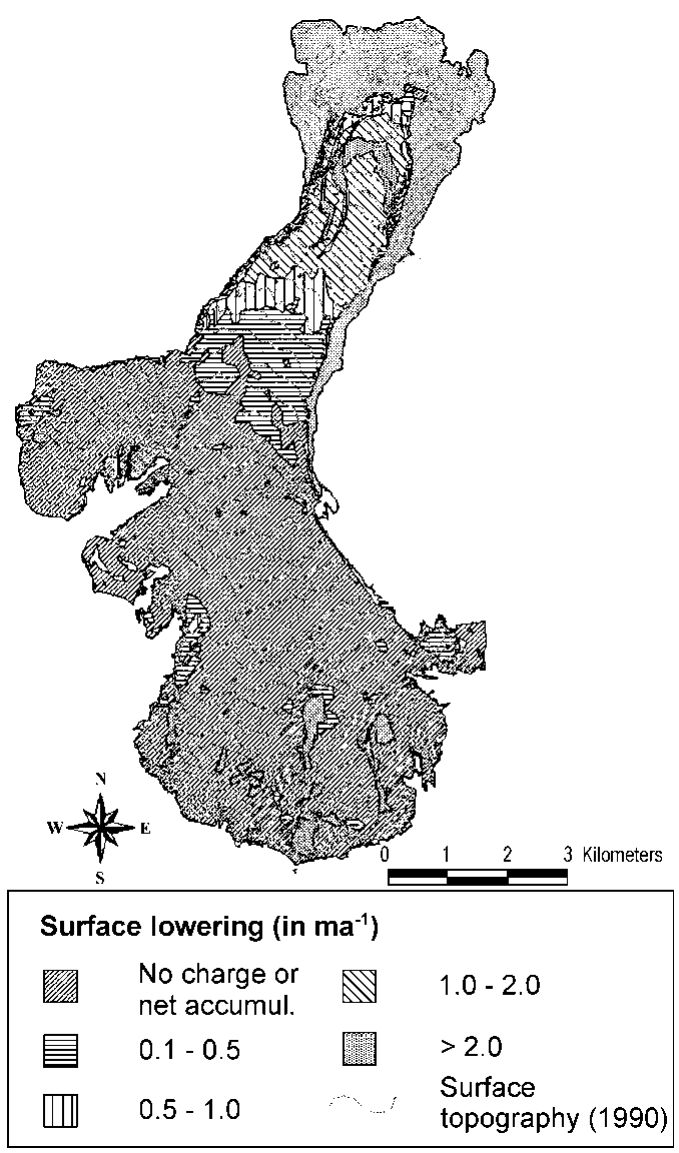

Fig. 3 Annual change in elevation, 1970-90, obtained by subtracting surface topography of the 1970 DEM from that of the 1990 DEM. 


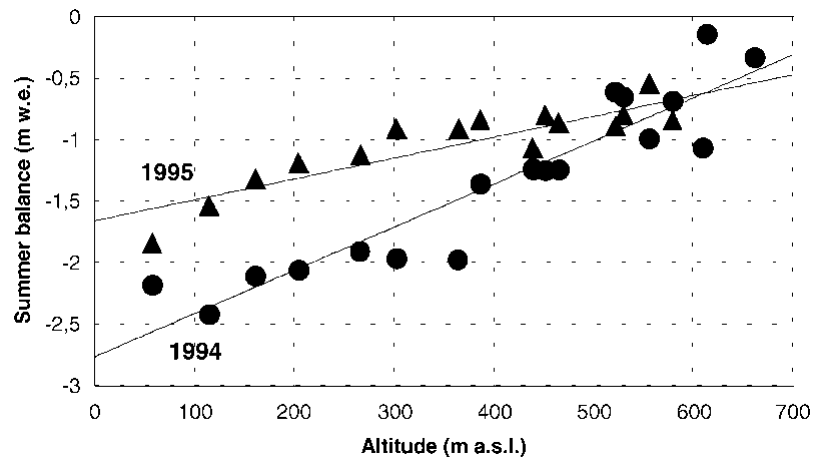

Fig. 4. Summer ablation gradients on the glacier, 1994 and 1995, calculated from stake readings (circles and triangles).

still probably the most reliable bed map that can be produced from the available data. The DEM of subglacial topography was then obtained by applying Hutchinson's (1989) interpolation procedure on the contours base map.

\section{Mass balance}

Mass balance has been measured intermittently since 1950, but only the net balance values were measured and often for 2 year periods (Hagen and Liestøl, 1990). The mean net balance for the period $1950-95$ is -0.4 to $-0.5 \mathrm{~m}$ w.e. This is as shown on other glaciers in Svalbard mainly due to high summer melting, giving here an extra annual runoff of about $14 \times 10^{6} \mathrm{~m}^{3}$, compared to a year with mass balance at equilibrium. For the period 1970-90 the mean net balance calculated by subtracting the DEMs was more negative, about $-0.65 \mathrm{~m}$ w.e. Superimposed ice forms over a large part of the glacier, delaying runoff and also affecting the ELA. The mean ELA is not well defined due to a complex accumulation pattern and differential melting. Thus the ELA varies from about $500 \mathrm{~m}$ a.s.l. in the western and central parts to nearly $700 \mathrm{~m}$ a.s.l. in the eastern part. The melting of snow and ice was measured during 1994 and 1995 by ablation stakes drilled into the ice (Fig. 4); these were the only years when both winter and summer balances were measured (Nuttall and others, 1997).

\section{Hydrology}

Water discharge was monitored at the outlet from the glacier during the 1994 and 1995 summers from 25 June to 19 and 14 August, respectively (Hodson and others, 1997; Wadham and others, 1997). The water was predominantly derived from a single outlet emerging on the western side of the terminus (Fig. 2). This outlet received about $90 \%$ of the total runoff from the catchment. The two measurement years were quite different: in 1994 the discharge ranged from 1 to $35 \mathrm{~m}^{3} \mathrm{~s}^{-1}$, giving a total runoff of $57 \times 10^{6} \mathrm{~m}^{3}$, while in 1995 the discharge ranged from 0.5 to $15 \mathrm{~m}^{3} \mathrm{~s}^{-1}$, giving a total of $24 \times 10^{6} \mathrm{~m}^{3}$. However, after the observation period in 1995 a sudden high outburst event occurred, so the 1995 value is too low.

The drainage pattern has been observed mainly from the air photos from 1970 and 1990 which show the supraglacial channels, the locations of the main outlets from the glacier and the drainage pattern in front of the glacier (Fig. 5). The main outlets come out as subglacial channels at the front. Icings or naled ice form every winter and cover a large part of the flat sandur area in front of the glacier. The formation of icings indicates that the glacier bed is mainly at the pressure-melting point. An esker area in the western side of the glacier front indicates a pre-1990 water-passage location in the glacier frontal area.

\section{Spatial modelling of drainage waterways and poten- tial discharge}

The driving force for the water flow in and under glaciers is the hydraulic potential. Calculations of the hydraulic potential are based on the ice-surface and ice-thickness gradients. The water-pressure potential at the base of a glacier $\left(\Phi_{\mathrm{b}}\right)$ is the sum of the elevation potential and the pressure potential (Shreve, 1972 ; Björnsson, 1988), defined as $\Phi_{\mathrm{b}}=\rho_{\mathrm{w}} g Z_{\mathrm{b}}+P_{\mathrm{w}}$,
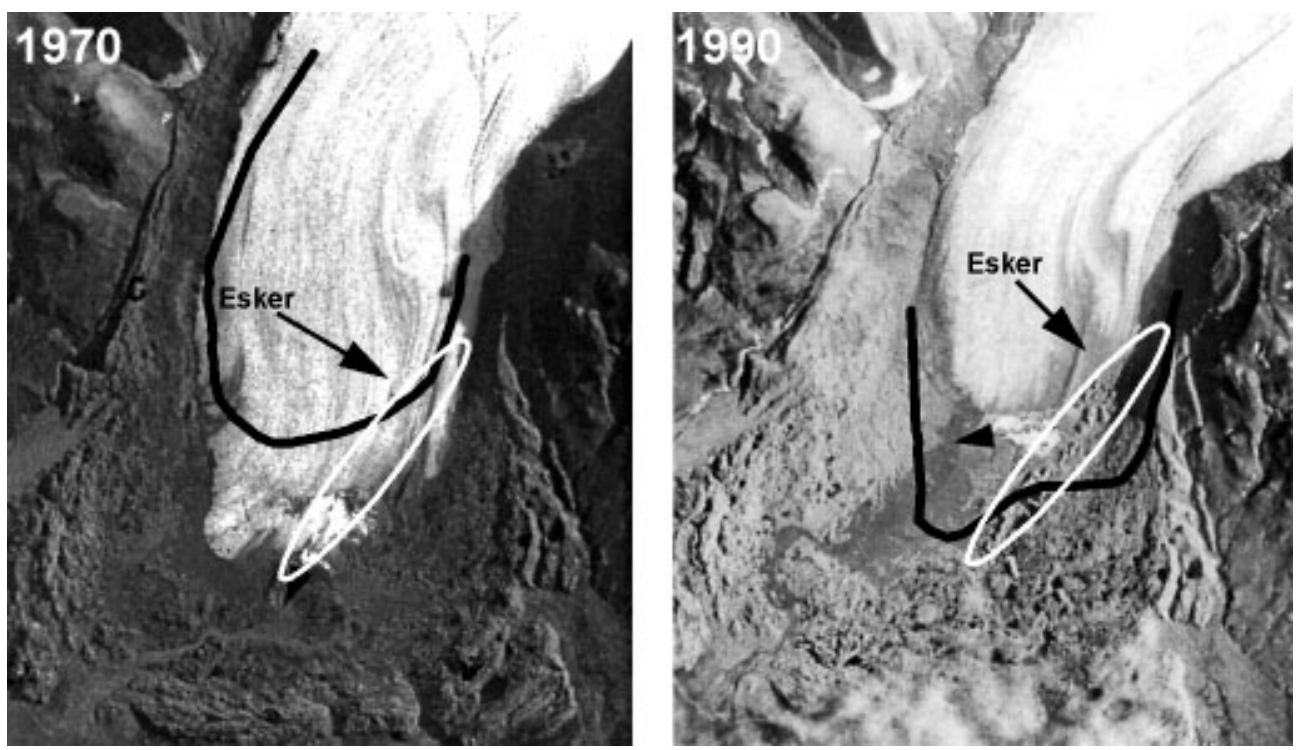

Fig. 5. Vertical air photos of the glacier front, 1970 and 1990. The black arrow shows the main direction of the stream forming the naled ice (icing) during winter. Black lines indicate the glacier front position in 1990 on the 1970 photo, and in 1970 on the 1990 photo. The esker that melted out from the glacier between 1970 and 1990 clearly indicates the location of the main water channel during that period. 


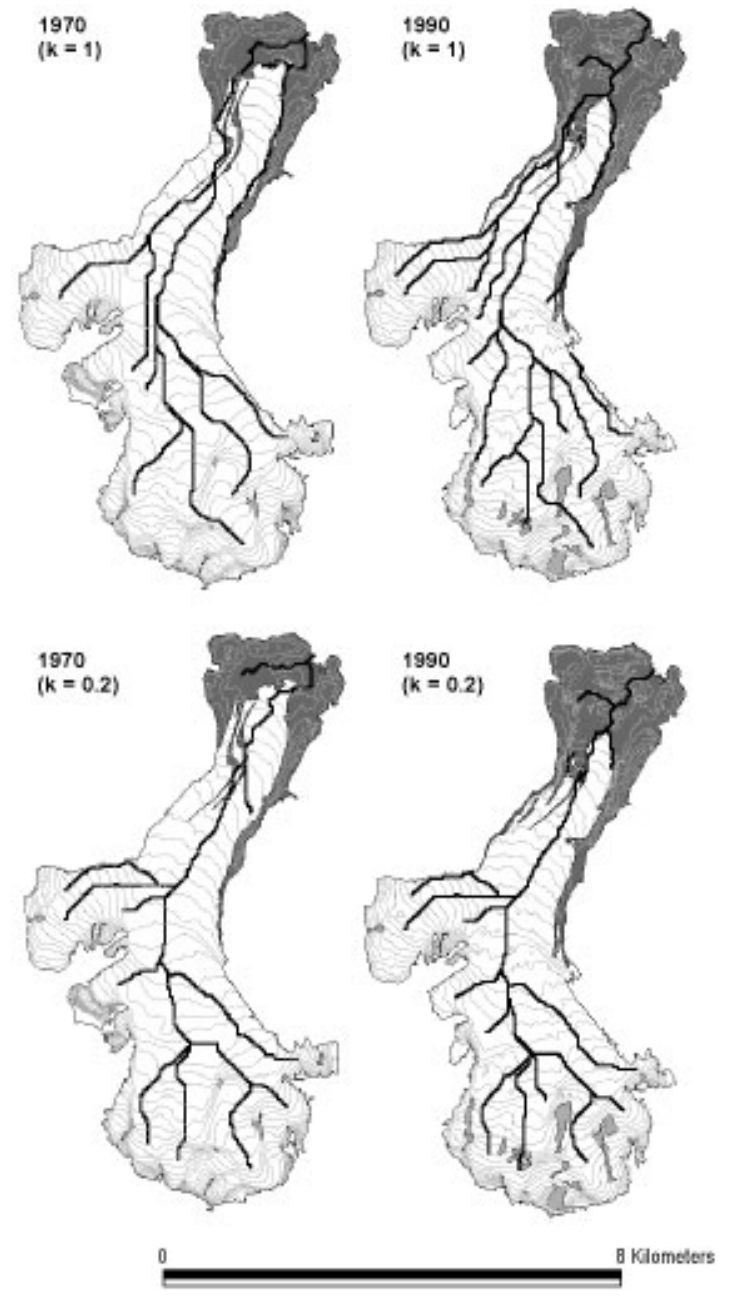

Fig. 6 Predicted waterways beneath Finsterwalderbreen, 1970 and 1990, for $k=1$ and $k=0.2$.

where $P_{\mathrm{w}}$ is the subglacial water pressure $P_{\mathrm{w}}=k \rho_{\mathrm{i}} g\left(Z_{\mathrm{s}}-Z_{\mathrm{b}}\right)$, i.e. proportional to the ice-overburden pressure. $Z_{\mathrm{s}}$ and $Z_{\mathrm{b}}$ are the elevations of glacier surface and bedrock, respectively, $\rho_{\mathrm{i}}$ is the density of ice, $\rho_{\mathrm{w}}$ is the density of water, $g$ is the acceleration of gravity, and $k$ is a factor between 0 and 1 representing the range of the water pressure in subglacial conduits from atmospheric pressure $(k=0)$ to full ice-overburden pressure $(k=1)$ when the channels are completely filled with water. The value $k$ can also be seen as the fraction of channels where the water pressure is equal to the ice-overburden pressure, giving pressurized channels with maximum influence of the ice for $k=1$, i.e. the direction of the subglacial channels is decided mainly by the gradient of the ice surface (ice-directed drainage). When $k=0$ the direction of the channels is determined by the gradient of the bed. The subglacial meltwater flows normal to the equipotential lines, which can be calculated by:

$$
\Delta \Phi_{\mathrm{b}}=\frac{\Delta\left(\rho_{\mathrm{w}} g Z_{\mathrm{b}}\right)}{\Delta s}+k \frac{\Delta\left(\rho_{\mathrm{i}} g h\right)}{\Delta s},
$$

where $\Delta \Phi_{\mathrm{b}}$ is the change in water potential along the direction of maximum potential drop, $\Delta s$ is a length measured in the direction of the maximum potential drop (the direction of water flow) and $h$ is the glacier thickness (Shreve, 1972).

GIS spatial analyzing capability based on map analysis concepts (Tomlin, 1990; Berry, 1993) was used to calculate the potential drainage system. Calculating approaches developed by Björnsson (1988) were utilized and applied two-

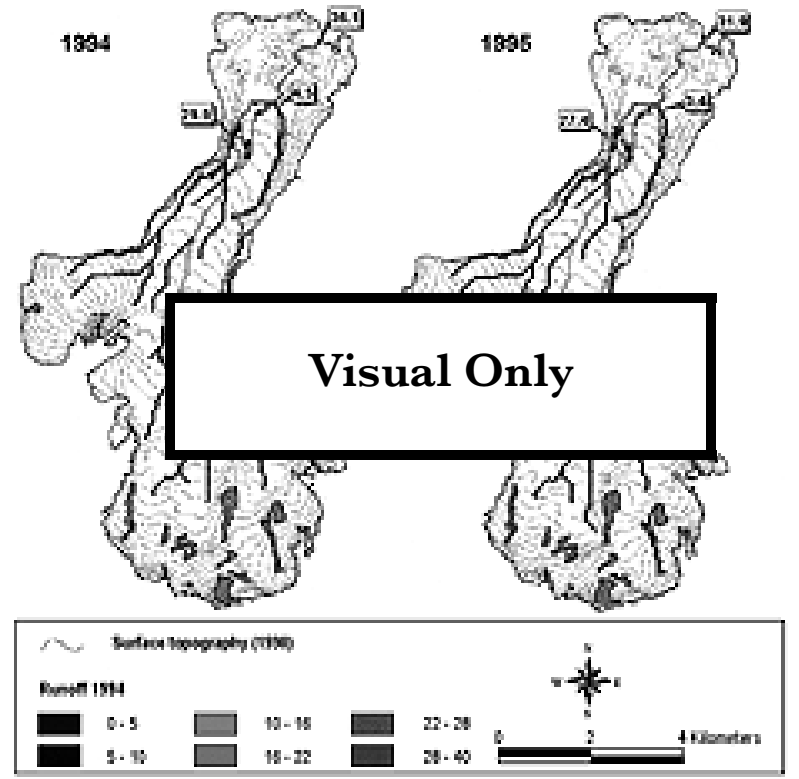

Fig. 7. Predicted total runoff, 1994 and 1995, in $10^{6} \mathrm{~m}^{3}$.

dimensionally. Etzelmüller and Björnsson (in press) describe the methods in more detail. The spatial map models describe a static glacier stage and do not integrate changes of mass balance or water pressure in channels during the year.

The flow direction is determined by adaptive filtering technique using the D8 algorithm (O'Callaghan and Mark, 1984). This algorithm describes the routine that decides in which direction the flow is routed in a local neighbourhood. For each cell the slope is tested in the eight nearest neighbours and the flow goes from that cell directed to the neighbour with the maximum slope. This may be a good approximation for subglacial water conditions (Kennett and others, 1997; Flowers and Clarke, 1999; Etzelmüller and Björnsson, in press). Then the numbers of neighbouring cells that drain towards each individual cell are counted. Finally, the drainage passages are defined as those areas where the accumulated number of cells draining to each individual cell exceed a defined threshold (Fig. 6). For calculation of the potential discharge a map of summer ablation is generated by establishing an empirical linear relationship between ablation and altitude (Fig. 4). This map is then used as input for the runoff calculations, resulting in potential discharges (Fig. 7).

\section{DRAINAGE PATTERN}

Our model is run for $k=1$ and $k=0.2$, reflecting the greater influence of the bed topography (Fig. 6). The estimate for $\Phi$ is expected to represent average values over distances of the order of the glacier thickness. In our study we have used an average thickness of $200 \mathrm{~m}$ of ice, and thus we have calculated pressure gradients as average values over a circle diameter of $200 \mathrm{~m}$ around each gridcell point. If we reduce the averaging distance we will include too many details of the surface topography compared to the details of the bedtopography map. We would rather increase the averaging distance to $250-300 \mathrm{~m}$, which would give more or less the same pattern and evolution.

Some studies conclude that most of the subglacial channels under valley glaciers of similar size to Finsterwalderbreen are an open-channel system (Hooke, 1984), while others conclude 
Table 1. Finsterwalderbreen hydrological data during summers 1994 and 1995

\begin{tabular}{|c|c|c|}
\hline & 1994 & 1995 \\
\hline Glacier surface area & $32.9 \mathrm{~km}^{2}$ & $32.9 \mathrm{~km}^{2}$ \\
\hline $\begin{array}{l}\text { Summer balance }\left(b_{s}\right) \\
\text { Average } \\
\text { Total water volume }\end{array}$ & $\begin{array}{l}-1.15 \mathrm{~m} \\
41 \times 10^{6} \mathrm{~m}^{3}\end{array}$ & $\begin{array}{l}-1.02 \mathrm{~m} \\
36 \times 10^{6} \mathrm{~m}^{3}\end{array}$ \\
\hline $\begin{array}{l}\text { Measured summer discharge } \\
\text { (measured in Chl; } \\
\text { cf. Hodson and others, 1996) }\end{array}$ & $57 \times 10^{6} \mathrm{~m}^{3}$ & $24 \times 10^{6} \mathrm{~m}^{3}$ \\
\hline $\begin{array}{l}\text { Modelled annual discharge } \\
\text { Meltwater channel, west (Chl) } \\
\text { Meltwater channel, east (Ch2) } \\
\text { Catchment outlet, north (Ch3) }\end{array}$ & $\begin{array}{l}29.9 \times 10^{6} \mathrm{~m}^{3} \\
4.5 \times 10^{6} \mathrm{~m}^{3} \\
36.1 \times 10^{6} \mathrm{~m}^{3}\end{array}$ & $\begin{array}{l}27.4 \times 10^{6} \mathrm{~m}^{3} \\
3.4 \times 10^{6} \mathrm{~m}^{3} \\
31.9 \times 10^{6} \mathrm{~m}^{3}\end{array}$ \\
\hline $\begin{array}{l}\text { Contributing area } \\
\text { Ch3 }\end{array}$ & $41.2 \mathrm{~km}^{2}$ & $41.2 \mathrm{~km}^{2}$ \\
\hline $\begin{array}{l}\text { Average specific discharge during } \\
\text { ing season (90 days) } \\
\quad \text { Ch3 }\end{array}$ & $113 \mathrm{~L} \mathrm{~s}^{-1} \mathrm{~km}^{-2}$ & $100 \mathrm{~L} \mathrm{~s}^{-1} \mathrm{~km}^{-2}$ \\
\hline Linear ablation gradient & $0.35 \mathrm{~m}(100 \mathrm{~m})^{-1}$ & $0.19 \mathrm{~m}(100 \mathrm{~m})^{-1}$ \\
\hline
\end{tabular}

that the channel system is mainly pressurized in a similar glacier (Kohler, 1995). For both the 1970 and 1990 glacier topography the model runs with $k=1$ (pressurized flow) give a closer fit to the observed locations than the model run with $k=0.2$ (mainly open-channel system). This indicates that the water passages are mainly directed by the glacier surface and thus that the channels are partly pressurized. As shown by Ødegård and others (1997), the glacier is at the pressuremelting point over most of its bed except within 500-700 m of the terminus. In this region the ice is thin $(h<70 \mathrm{~m})$ and cold, and therefore deforms very slowly. It is therefore likely that the water channels are open and stable in this section and then are gradually filled upstream. The pressurized flow probably starts in the part of the glacier where it is $>150 \mathrm{~m}$ thick and where the ice below $100 \mathrm{~m}$ depth is at the pressuremelting point, i.e. about $1.5 \mathrm{~km}$ from the front. In this part the channels are partly pressurized and $k \in(0.2,1)$ but to a large extent closest to 1 .

The channels at the bed will follow in detail the locations where the pressure is smallest. The pressure gradients will always decide where the water will flow. Our analysis does not give these details, as our bed-topography map is inadequate for this purpose. Our analysis also omits seasonal variations and pressure gradients inside the channels due to seasonal or even daily variations in the water discharge. Our simplified analysis gives only the overall pattern.

The drainage pattern of the glacier is stable from one year to the next; it changes only when the glacier geometry changes as the glacier retreats. The drainage pattern over the period 1970-90 shows a change in the predicted location of the main outlet stream from the glacier. In 1970 the main stream escaped close to the central part of the front, while after the retreat of the front and lowering of the surface the river changed course to a more westerly location under the glacier and at the outlet (Fig. 6). This change can also be observed on the vertical air photos of the glacier front in 1970 and 1990 (Fig. 5). The esker that emerged as the glacier retreated between 1970 and 1990 clearly indicates the location of the main water channel during that period. In both years the icing (naled ice), which is a result of winter discharge from the glacier, was formed mainly in front of the central part of the glacier. This is because in 1990 the unfrozen winter water also drains along the glacier front to the central part after it has emerged from the glacier via the western outlet as shown in Figure 5.

The change of the channels in the study period also affected the contributing area of the western and eastern outlets. While in 1970 the western outlet drained $85 \%$ of the glacier area $\left(34 \mathrm{~km}^{2}\right.$ vs $5.8 \mathrm{~km}^{2}$ for Chl and Ch2 (see Fig. 2), respectively), this proportion increased to $91 \%$ in 1990 (32 $\mathrm{km}^{2}$ vs $3 \mathrm{~km}^{2}$ for Chl and Ch2, respectively). This may have an effect on the flow behaviour of the glacier, and must be considered when surge build-up situations are discussed.

\section{POTENTIAL DISGHARGE}

The main sources of runoff during summer are (1) melting of snow and ice on the glacier surface, (2) snowmelt from areas in the drainage basin outside the glacier, and (3) summer rainfall. In this drainage basin the glacierage cover is nearly $70 \%$. It has been shown for other basins in Svalbard with similar glacierization that melting on the glaciers is the predominant source of meltwater, contributing more than twothirds of the total runoff (Hagen and Lefauconnier, 1995). It has also been shown that there is a very high correlation between summer ablation and the total discharge from the glacier because runoff variation is mainly due to summer temperatures, and thus ablation could be used to estimate the total runoff. The other source of runoff variation was summer rainfall which was highly variable from year to year. Snowmelt from ice-free areas makes a fairly stable contribution, as annual snowfall does not vary much. Thus, a linear regression model was fitted to the ablation data (Fig. 4). The resulting regressions explained $>75 \%$ of the original variations. The regression coefficients were then used to calculate a distributed map of the summer balance, and potential discharge was estimated (Fig. 7).

The model predictions of the calculated potential contribution of runoff in each river outlet were compared to the field measurements in the meltwater rivers (Hodson and others, 1997). The relative importance of the two outlets (Chl and Ch2; cf. Fig. 7 and Table 1) fits well with the observed values. However, the modelled absolute values showed a much lower runoff than measured in 1994, while the opposite was true in 1995. The 1995 discrepancy could be due to heavy rainfall during that summer or to englacial or subglacial water storage. Some observed sudden high-runoff events, especially in 1995, could indicate release of this kind of storage, but we do not have enough detailed data to evaluate this further. However, in 1995 the measured discharge is clearly underestimated, as a sudden runoff event was not monitored after the observation period. Therefore, the 1995 values should be very close to the actually observed situation.

\section{CONCLUSIONS}

(1) The modelling of the subglacial drainage indicates that the subglacial channels under Finsterwalderbreen are partly pressurized, and their location directed by the glacier except for the lowermost $1.5 \mathrm{~km}$ near the terminus where the glacier is cold and thin. 
(2) The western outlet of Finsterwalderbreen drained a larger area in relation to glacier size in 1990 than in 1970, which may affect glacier flow.

The estimated absolute runoff values did not correspond very well with measured summer runoff. This is due to heavy summer rain in 1994 and a possible subglacial water-storing system which causes sudden runoff events.

\section{ACKNOWLEDGEMENTS}

The first two authors should be regarded as having contributed equally to this paper. M. Kennett and S.-E. Hamran did the radar soundings. T. Tonning carried out most of the radar data interpretation and interpolation work. A. Hodson provided the discharge data. This work was supported by EU grant EN5V-CT93-0299 "Investigations of Glacier Surges: Measurements and Modelling of Ice Dynamics in Svalbard", and at a later stage by a contribution from EU grant ENV4-CT97-0490, "The Response of Arctic Ice Masses to Climate Change: Modelling, Remote Sensing and Field Measurements". All digital spatial analysis was carried out at the Laboratory for Remote Sensing and Geographical Information Technology at the Department of Physical Geography, University of Oslo. The authors want to thank all the persons and institutions mentioned.

\section{REFERENCES}

Berry, J. K. 1993. Cartographic modelling: the analytical capabilities of GIS. In Goodchild, M. F., B. O. Parks and L. T. Steyaert, eds. Environmental modeling with GIS. Oxford, Oxford University Press, 56-74.

Björnsson, H. 1988. Hydrology of ice caps in volcanic regions. Visindafélag Ísl. Rit. 45.

Björnsson, H. 1998. Hydrological characteristics of the drainage system beneath a surging glacier. Nature, 395(6704), 771-774.

Björnsson, H. and 6 others. 1996. The thermal regime of sub-polar glaciers mapped by multi-frequency radio-echo sounding. F. Glaciol., 42(140), 23-32.

Etzelmüller, B. 2000. On the quantification of surface changes using gridbased digital elevation models (DEM). Trans. GIS., 4(2), 129-144.

Etzelmüller, B. and H. Björnsson. In press. Analysis of digital elevation models for glaciological applications. Int. F. Geogr. Inf. Sci.

Etzelmüller, B. and J. L. Sollid. 1997. Glacier geomorphometry - an approach for analyzing long-term glacier surface changes using grid-based digital elevation models. Ann. Glaciol., 24, 135-141.

Flowers, G. E. and G. K. C. Clarke. 1999. Surface and bed topography of Trapridge Glacier, Yukon Territory, Canada: digital elevation models and derived hydraulic geometry. F. Glaciol., 45(149), 165-174.

Fox, A. J. and A.-M. Nuttall. 1997. Photogrammetry as a research tool for glaciology. Photogramm. Rec., 15(89), 725-737.

Hagen, J. O. and B. Lefauconnier. 1995. Reconstructed runoff from the high Arctic basin Bayelva in Svalbard based on mass-balance measurements. Nord. Hydrol., 26(4-5), 285-296.

Hagen, J. O. and O. Liestøl. 1990. Long-term glacier mass-balance investigations in Svalbard, 1950-88. Ann. Glaciol., 14, 102-106.

Hamran, S.-E. and E. Aarholt. 1993. Glacier study using wavenumber domain synthetic aperture radar. Radio Sci., 28(4), 559-570.

Hodson, A. J., M. Tranter, J. A. Dowdeswell, A. M. Gurnell and J. O. Hagen. 1997. Glacier thermal regime and suspended-sediment yield: a comparison of two high-Arctic glaciers. Ann. Glaciol., 24, 32-37.

Hooke, R. LeB. 1984. On the role of mechanical energy in maintaining subglacial water conduits at atmospheric pressure. f. Glaciol., 30(105), 180-187.

Hutchinson, M. F. 1989. A new procedure for gridding elevation and stream line data with automatic removal of spurious pits. F. Hydrol., 106, 211-232.

Kamb, B. 1987. Glacier surge mechanism based on linked cavity configuration of the basal water conduit system. F. Geophys. Res., 92(B9), 9083-9100.

Kamb, B. and 7 others. 1985. Glacier surge mechanism: 1982-1983 surge of Variegated Glacier, Alaska. Science, 227(4686), 469-479.

Kennett, M., C. Rolstad, H. Elvehøy and E. Ruud. 1997. Calculation of drainage divides beneath the Svartisen ice-cap using GIS hydrologic tools. Nor. Geogr. Tidsskr., 51 (1), 23-28.

Kohler, J. 1995. Determining the extent of pressurized flow beneath Storglaciären, Sweden, using results of tracer experiments and measurements of input and output discharge. F. Glaciol., 41 (138), 217-231.

Liestøl, O. 1969. Glacier surges in west Spitsbergen. Can. F. Earth Sci., 6(4), Part 2, 895-897.

Nuttall, A.-M., J. O. Hagen and J. Dowdeswell. 1997. Quiescent-phase changes in velocity and geometry of Finsterwalderbreen, a surge-type glacier in Svalbard. Ann. Glaciol., 24, 249-254.

O'Callaghan, J. F. and D. M. Mark. 1984. The extraction of drainage networks from digital elevation data. Computer Vision, Graphics and Image Processing, 28, 323-344.

Ødegård, R. S., J. O. Hagen and S.-E. Hamran. 1997. Comparison of radioecho sounding (30-1000 MHz) and high-resolution borehole-temperature measurements at Finsterwalderbreen, southern Spitsbergen, Svalbard. Ann. Glaciol., 24, 262-267.

Paterson, W. S. B. 1994. The physics of glaciers. Third edition. Oxford, etc., Elsevier.

Shreve, R. L. 1972. Movement of water in glaciers. F. Glaciol., 11(62), 205-214.

Tomlin, C. D. 1990. Geographic information systems and cartographic modeling. Englewood Cliffs, NJ, Prentice Hall.

Wadham, J. L., A. J. Hodson, M. Tranter and J. A. Dowdeswell. 1997. The rate of chemical weathering beneath a quiescent, surge-type, polythermalbased glacier, southern Spitsbergen, Svalbard. Ann. Glaciol., 24, 27-31. 